\title{
Homelessness and Covid-19 in the City of Tshwane: Doing liberation theology undercover - A conversation with Ivan Petrella
}

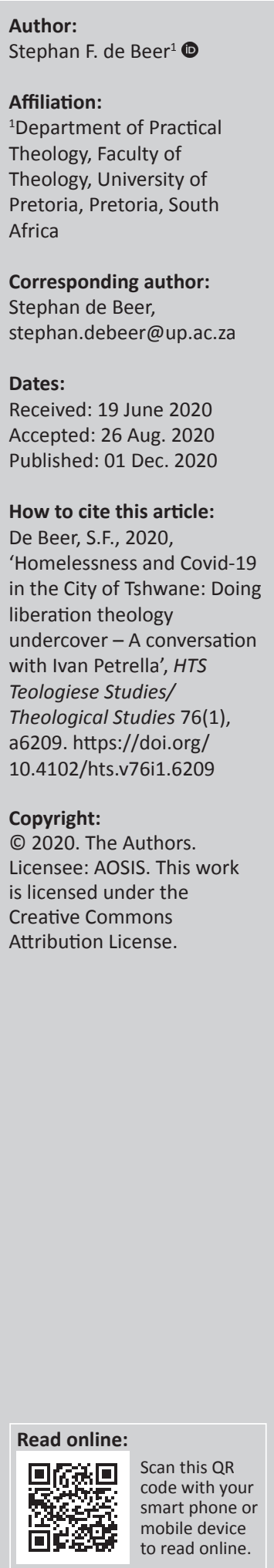

Ivan Petrella argues that the goals of liberation theology can sometimes be better served by doing it undercover. This article reflects on responses to homelessness during Covid-19 in the City of Tshwane, describing and reflecting upon it from the perspective of a researchertheologian as well as activist-urbanist. It employed two lenses in its reflection: Petrella's notion of the 'undercover liberation theologian', as well as what is known as deliberative public administration theory, as possibly complementary approaches. It traces ways in which people of faith/theologians participated in the City of Tshwane through means other than explicit theological discourse. It implies that such engagement was not less theological but perhaps more strategic, describing that task of the undercover liberation theologian as that of making space, making plans, making known and making change. Ultimately, it calls for a subversion of suspect models of theological education, suggesting that it is in losing ourselves in the messiness of public processes and multiple solidarities with the poor, that the unfree might experience freedom, and liberation theological goals might find concrete expression.

Contribution: This article reflects on responses in the City of Tshwane to street homelessness during Covid-19. It unpacks the notion and role of the 'undercover' liberation theologian in local political processes, and how losing ourselves in public processes and multiple solidarities with the urban poor, might help gain freedom for the unfree.

Keywords: street homelessness; undercover liberation theologian; deliberative public administration; making space; making plans; making known; making change.

\section{The visibility of homelessness: Surfacing fault lines and hard-heartedness; evoking kindness and bold alternatives ${ }^{1}$}

The invisibility of homelessness, or the pretensions of invisibility, has in many places changed during Covid-19 to make homeless persons acutely visible. What accentuated this in South Africa was that, on announcing the lockdown, President Ramaphosa (2020) also said that temporary shelters had to be created for homeless people. However, there was no framework or blueprint to accompany the President's call.

This meant that every municipality was on its own in terms of trying to find ways to suddenly shelter thousands of homeless persons; something many municipalities shied away from for decades. This call of the President, charging local government to shelter homeless people, surfaced many different things. I highlight only four of those at the beginning of this article.

It immediately revealed institutional fault lines: backlogs in infrastructure; the lack of policy and budgets at national and local levels to deal with homelessness; the lack of organised networks in different cities that could deal with homelessness collaboratively; weak civil society in the face of - in some cases - brutal and inappropriate government interventions; and ambiguous, to say the least, church responses (cf. De Beer 2020a).

It exposed hard hearts: some neighbourhoods who always wanted to find ways of getting rid of 'their' homeless problem could now enforce the displacement of people into temporary shelters, not as acts of care but as acts of criminalising homeless people away from their neighbourhoods. In many

1.This article is based on a paper read in an online seminar, jointly hosted by the Graduate Programme in Theology of the Pontifical Catholic University of Paraná at Curitiba, Brazil, and the Beyers Naude Centre for Public Theology at Stellenbosch University, Stellenbosch, South Africa. 
cases, those who made the loudest noise about the presence of homeless persons refrained from responding as loudly by failing to create shelters where people were found in these neighbourhoods.

Firstly, and the complete opposite: the call to shelter homeless people evoked what Wilna de Beer referred to as unusual kindness. It was the kind of kindness that Paul and his companions found on arriving on the island Malta shipwrecked and foreigners. And it says in Acts 28:2:

The islanders showed us unusual kindness. The islanders showed us unusual kindness. They built a fire and welcomed us all because it was raining and cold.

An outpouring of unusual kindness got unleashed - the kind that is not necessarily part of our DNA anymore. And this has been evident in shelters all across the city.

Secondly, it showed that it was indeed possible to provide shelter for 1500 to 2000 people in relatively decent ways in only 10 days, if there was sufficient pressure, political will, civic freedom to do what they know best and collaboration between the different actors.

\section{Homelessness and Covid-19 in the City of Tshwane ${ }^{2}$}

The process of prioritising homeless persons in our city - as an option for the poor and their access to just alternatives to homelessness - started many years ago when some of us started to work alongside homeless and other vulnerable communities in the inner city

\section{4-early 2020}

Then, in 2014, a shelter owned by the city, but not managed, and in a horrible condition, with threats of being closed down and lost as a shelter for homeless persons, became a catalyst for collaboration. Some of us met the Executive Mayor about this shelter. The result of the meeting was a request from the Mayor that we should conduct research and advise the city on a policy for homelessness.

This became a good opportunity to rally researchers, at both the University of Pretoria and the University of South Africa, coming from different disciplines, and desiring to engage homelessness through research. We brought together this team of researchers, with practitioners, (former) homeless persons and city officials, designing a transdisciplinary research project on homelessness, known as 'Pathways out of homelessness', with a clear aim of influencing policy, through placing homeless persons, their dignity and holistic freedom, central on the city's agenda (cf. De Beer \& Vally 2015).

A number of concrete results came out of this collaborative process:

- The first-ever Tshwane Homeless Summit was hosted, drawing together 400 people, including 200 homeless

2.The City of Tshwane is the name of the metropolitan municipality to which Pretoria belongs. It is the administrative capital city of South Africa. persons, to engage the tentative research findings, based upon which policy and strategic inputs were made. Renkin and De Beer (2017:482-496) write about this Summit as dramaturgy, gathering various actors on a collective stage, partly predetermined and partly allowing for 'dissensus, irruption and surprise' (Renkin \& De Beer 2017:482).

- An extensive street medicine programme was launched, under the leadership of the Department of Family Medicine at the University of Pretoria, providing direct access to primary health care for homeless persons on the streets and in shelters where they were, and also access to harm reduction programmes for substance-using homeless persons (cf. Hugo 2017:14-17).

- Awareness-raising workshops were created by the Centre for Faith and Community at the University of Pretoria, to deal with myths about homelessness amongst law enforcement agencies, journalists, churches and city officials (cf. De Beer \& Vally 2015:70). The idea was to mobilise 'homeless champions' in these sectors who were able to help dispel myths and create a new consciousness amongst peers about how they viewed homeless persons and made decisions to include or exclude them from the city.

- A strong resolution was for decentralising some of the services that were concentrated in central parts of the city, to now also be rolled out in new concentration points where homeless people lived. This was in alignment to one of the clear research findings, which identified the suburbanisation of homelessness and the increasing number of working people opting for temporary homelessness as a livelihood strategy. This relates to the spatial structure of South African cities, in which the concentration of the economy and the availability of affordable housing are often completely separated, meaning long travelling distances for the working poor, much time away from their families and restrictive costs of public transport. In response, an increasing number of people choose to stay on the streets to save money and send it back to where their families are (cf. De Beer \& Vally 2015:63-65, 67).

- A significant outcome of the research process was the drafting of a Policy and Strategy on Street Homelessness in the City of Tshwane (cf. De Beer \& Vally 2015:53-61). Unfortunately, this policy and strategy was only adopted in 2019, 4 years and 3 Mayors later (City of Tshwane Metropolitan Municipality 2019; Ntuli 2019). Although being adopted, no budget was approved to ensure the implementation of this policy, making it a rather toothless document. The adopted policy made homelessness more visible, to an extent, and became a lever for civil society in our engagement with the city, but, clearly, it was not yet one of the city's priorities.

\section{Fast forward: Lockdown during Covid-19 in the City of Tshwane}

Then it became March 2020, the week before lockdown for Covid-19 in South Africa. Some of my colleagues tried to get an 
audience with the people responsible for homelessness in the city government. They actually met briefly, twice, but were laughed at, and told by the city officials that currently there were no politicians in the city (our city at this point was under administration), and therefore they had no mandate to act at all!

A few days later the President announced a national lockdown, and insisted in his speech on opening shelters for homeless persons. Suddenly, our city's failure to implement its brand new policy and strategy, that were forged through a very exciting and bottom-up participatory process, became clear for all to see.

Without anybody being ready, and without sufficient preparations being made, the city then, out of necessity and in great rush, opened an abandoned soccer stadium for homeless persons around the 28th of March 2020. Within days there were 2000 people congregating, wanting food and shelter, but there were only tents and mattresses for about 150 people. Much embarrassment, a stampede for food and rubber bullets being shot at the crowds, and daily media exposure, fortunately helped force the city to look for alternatives to divert people to move elsewhere (cf. Allison \& Harper 2020).

In the meantime, 2 days or so before the stadium opened, the Tshwane Homelessness Forum, which is a broad-based forum of the homelessness sector in the city, was able to force a meeting with the city, to call out their lack of responsiveness. This forum represents most of the non-profits doing meaningful work with homeless communities, former and current homeless people, as well as researchers from universities. Three difficult meetings were held, and eventually the forum was asked to draft and present a plan for managing homelessness during lockdown.

On the 29th of March, such a joint plan between the City of Tshwane and the Tshwane Homelessness Forum was adopted by the Group Head: Community and Social Development Services in the City of Tshwane ${ }^{3}$ The plan was meant to guide the collaborative process committed to provide safe spaces to homeless people.

A week later, the stadium was closed, after a number of alternative sites were identified across the city, opening up as shelters and, eventually, accommodating almost 1800 people within 10-20 days.

Two smaller sport grounds accommodated 300 persons each; a charismatic church opened its facility for 91 homeless men using substances; a homeowners' association opened a tented shelter in a public park and managed it themselves; 3 inner city churches opened their spaces, and a suburban church in a gated community opened up for 20 older homeless men, amongst some initial protest from neighbours; soon 4 other suburban churches followed; an non-governmental

3.This plan, drafted by the Tshwane Homelessness Forum and adopted by the City of Tshwane's Department of Community and Social Development Services, was titled Tshwane's Department of Community and Social Development Services, was titled
'Covid-19 Proposed Plan for Physical Distancing, Social Isolation and Reduced Risks 'Covid-19 Proposed Plan for Physical
for Homeless Persons in Tshwane'. organisation (NGO) in the city opened 19 bed spaces for older homeless persons with special needs and are converting a social housing facility into accommodating another 30-36 older homeless persons (cf. De Beer 2020b).

An exciting model has unfolded of collaborative shelter management, drawing on the strengths of different partners, and giving clues as to a better way going forward, beyond individual organisational interests through a 'shared services approach' (cf. De Beer 2020b).

\section{Seizing a post-lockdown opportunity}

Personally, some weeks into the process I described above, I became more involved in facilitating the construction of a post-lockdown plan, which is really finding a way of operationalising the city's dormant policy on homelessness, now enabled by the crisis of Covid-19. ${ }^{4}$

This plan is focusing on creating 1250 permanent bed spaces (new) over the next 12 months in every region of the city, accompanied by psycho-social and healthcare programmes, economic access and vocational training, and implemented by a joint institutional vehicle, formed between the City of Tshwane, the Tshwane Homelessness Forum and the participating Universities.

During the whole lockdown period, Professor Jannie Hugo from the Department of Family Medicine at the University of Pretoria was responsible for coordinating the roll-out of primary healthcare services and harm reduction programmes to all the shelters and also to people who still live on the streets. They are now finding ways to institutionalise their approach beyond lockdown and Covid-19, as the 'new normal' in primary healthcare for very vulnerable populations.

More than 20 organisations contributed to this collaborative intervention. It included city officials, NGOs, faith-based organisations, researchers and volunteers, all coming from different places, yet seeking to find a sense of common ground. It was a frail collaboration in which push-backs happened on an almost daily basis, negotiating space, winning some ground, pausing, then moving ahead again.

Similar processes happened in many cities across South Africa. It played itself out in different ways in these cities. A National Homeless Network, made up of representatives from at least nine cities, called in with each other on a weekly basis to compare notes and shared good, and bad, practices. We learnt from each other, as we all participated in this organic process of building a response, on the run.

\section{Reflections of a researcher- theologian and activist-urbanist}

In this section, I reflect personally on the meaning of the above, trying to make sense both personally and vocationally 4.10-Point Action Plan for Re-Integrating Homeless People: Operationalising the Tshwane Homelessness Policy and Strategy. 
of this intense journey. I try to discern how it relates to my work as a researcher and theologian at the university, and my commitment as an activist to open up urban spaces that will be just and inclusive, particularly for the most vulnerable communities of the city.

At first glance, for some, it does not make sense. Some even say I am doing two different jobs. The worlds of the streets, public policy-making, the academy, the church and NGOs are all markedly different. There are different values, goals, organisational cultures and bottom-lines that often seem contradictory and distanced from each other.

At second glance, though, is this not what we are invited to as theologians in a complex, postcolonial global city? Navigating space from the perspective of the urban poor, during Covid-19 lockdown, becomes the perfect space in which to fuse these worlds. As Gutierrez (1988:12) reminded us, liberation theology is not a new discipline in theology to be studied, but $a$ different way of doing theology. The danger is to co-opt liberation theological symbols or jargon, turning it into abstractions and new orthodoxies, without no longer practising concrete solidarity with the poor. When that happens, what is still called liberation theology now runs the risk of ceasing to still offer tools of liberation, in concrete terms (cf. Vellem 2015).

Another danger is this: when the bus of potential freedom arrives, for those of us seeking for liberation, the great danger is that we do not see the bus; or we do not recognise it, when we see it; or we simply do not get on because we are so used to fighting 'them' from the outside, that we do not know how to behave inside the bus. We do not have the language, or the skills. Covid-19 presents new opportunities to advance on a liberating agenda, but it raises new questions and requires new forms of engagement from those considering themselves liberation theologians. How to break down the walls from inside - for example, in public policy-making processes now becomes another strategic question and consideration for our alternative imaginations.

I want to reflect on it using two lenses: Ivan Petrella's (2017) notion of the undercover liberation theologian, and also a theory known as deliberative public administration (DPA) (Baccaro \& Papadakis 2008).

\section{Petrella's undercover liberation theologian}

The Boffs (1986:17-29), early on in liberation theology's formation, spoke of three kinds of liberation theologians: professional liberation theologians located in the academy; pastoral liberation theologians, pastoring local faith communities; and popular liberation theologians who are those deep in the trenches of local struggles - be it homelessness, landlessness, labour issues or gender violence. Petrella (2017:1) now added a fourth category, which he refers to as undercover liberation theologians.

Petrella's (2008:148, 2017:1) basic argument is that liberation theology today will achieve its goals beyond theology.
Theology in our postmodern and postcolonial society does not always have the stature, positionality, experience or language to be heard in conversations about land reform, economic systems, urban futures, ecological disaster or public health. It is beyond theology, in those spheres where futures are designed and constructed, where the imperatives of liberation theological imaginaries are to be fleshed out, but in languages that can shape the discourse and move the liberationist agenda along.

Petrella (2017) wonders if more justice would not be done to liberationist goals by the so-called undercover liberation theologian, who fleshes out liberationist priorities, without necessarily using theological jargon, in new spheres of engagement. It is not about hiding his and/or her theological points of departure, but of translating it into language accessible in various disciplines. There is resonance between Petrella's proposal and the work of Groody and Gutierrez (2013), arguing for liberation theology beyond theological discourses. The undercover liberation theologian does not use the theological jargon of liberation theology, but advocates the core concepts in disciplinary guise (Petrella 2017:1), whilst working as urban planners, public health workers, economists or agriculturalists, transforming 'the disciplines' presuppositions', in the words of Petrella (2008:148), through foregrounding justice for the poor. As an example, Petrella (2008:149; 2017:332-333), refers to the work of medical anthropologist, Paul Farmer, who considers healthcare systems from the perspective of opting for the poor. Farmer's is a deeply embodied liberating praxis, without necessarily using theological jargon.

Instead of compromising on its option for the poor, what is proposed here are deeply embodied forms of exercising such an option. Disembodied forms of liberation theology, that are neither attached to the lived experiences of those excluded or suffering nor engaged in concrete struggles for liberation however big or small this might be - run the risk of becoming intellectual orthodoxies without liberatory potency, or pseudo-radicalism, unable to translate themselves into concrete imaginaries and actions for liberatory change.

The question running through this section goes like this: How do we do our work to further an agenda of radical freedom from exclusion with the city's most vulnerable, without being in positions where we might actually further that agenda?

\section{Deliberative public administration theory versus Habermas's deliberative politics}

That brings me to a second lens, which is that of the so-called DPA, which I will briefly juxtapose along with Habermas's deliberative politics.

Deliberative public administration theory is sceptical about 'the problem-solving capacities of the state' (Baccaro \& Papadakis 2008:5) and advocates 'the devolution of as many decision-making prerogatives as possible from centralised bureaucracies to policy-making fora in which citizens 
participate either directly or (more frequently) through their representative bodies'. The emphasis of these proposed forums is to ensure that participants share not only insight into the problems they themselves face but that they also offer solutions. This echoes strongly with the rationale behind the participatory research on homelessness in our city, the Tshwane Homeless Summit, as well as collaborative engagement to forge a Covid-19 homelessness plan, and a post-lockdown operational plan.

On the other hand, Habermas's (1992:371-372) deliberative politics takes a different view. A deliberative politics consists of 'vibrant and independent civil society organizations', acting as - in his words - 'democratic vigilantes', that formulate and propose radical alternatives, but, in doing so, always refrain from direct involvement in the resolution of problems. Habermas advocates that it should remain this way. Firstly, because he opines that civil society lacks the capacity for public problem-solving, but also does not have the governance mandate to start with. But, and these might be his deeper concerns even, he is concerned that direct involvement carries with it certain grave risks: the ability to offer critique, independently, can be compromised; cooption by political heads becomes possible; radically innovative, independent and even disruptive actions showing a different way might be toned down. Based on these reservations, Habermas proposes that these civil society organisations remain working, critically and imaginatively, from the outside.

Advocates of DPA would question Habermas's optimism about public sector's ability to solve problems or make ethical decisions that are in the interest of the common good. To the contrary, for such decisions that uphold and advance the common good to be taken, they insist on flatter organisational structures and the necessity to invite diverse knowledges also of broad-based civil society actors - into decision-making processes (cf. Baccaro \& Papadakis 2008:12, 51).

I submit that it does not have to be the one or the other. The tension between these two approaches is a creative one that should persist. For it to remain a creative, and critical, tension however, not to be dissolved easily, a number of checks and balances need to be firmly in place.

Firstly, participation in public policy processes should never be done naively, but, for theologians of liberation, always with a hermeneutic of suspicion.

Secondly, the work of engaging policy should not replace the important and ongoing work of building innovative demonstration projects that embody the alternatives one agitates for. Both engaging policy and building demonstration projects go beyond mere imagination.

Thirdly, engaging policy should come from a place of deep embeddedness in communities. The primary interlocutors should remain the communities and voices the proposed policy purports to address. Policy formulations should and those participating in policy making should be made accountable, scrutinised and assessed by those very communities.

Finally, if the tension becomes such that something can break, Baccaro and Papadakis (2008:51) say there should be an exit option. Civil society, and in this case the undercover liberation theologian, should have the prerogative of exiting whenever necessary. Maybe one can call it our 'manipulative asset': the possibility of withdrawal when the city can least afford it.

\section{The task of the undercover liberation theologian: Making space; making plans; making known; making change}

Now, let me return to the homeless shelters and Covid-19 in our city. I want to think about the work of the undercover liberation theologian. Here, I use the term 'very liberally', referring to all those who practice their faith - in Jesus, or in the possibility of a new deal for the excluded poor - in ways that prioritise those considered poor and unjustly excluded. These might be professional theologians, clergy, laity, community workers, health workers or community activists. I think of their work - as undercover liberation theologians as the work of making space, making plans, making known and making change.

\section{Making space}

From one angle, for a brief moment, we can say that the efforts that went into making space for those ordinarily excluded was a practical expression of exercising an option for the poor. Making space, theologically, is about 'affirmation, i.e. the constitution of human identity' (Louw 2008:437). It is about acknowledging those often erased by dominant narratives.

Some participants in this process clearly did it from the perspective of opting for the poor. Others signed up to participate as an expression of deep compassion, affirming the homeless stranger, and embracing their humanity. Still others, by virtue of their job descriptions, were instructed to participate. The difference between different individuals and groups, and their motivations to be present in the shelter spaces, sometimes became evident in how different shelters were run, how homeless persons were included, or not, in decision-making about their own lives and futures, and how diligently long-term alternatives were being mediated.

Space is not neutral nor is making space. In the context of street homelessness, it is about asserting a right to the city for those too often denied this right. Kriel, Tembe and Mashava (2017:428) describe how a lack to a right to the city for homeless persons 'affects their daily lives ... the challenges the face on a daily basis and the different strategies they implement in mitigating these challenge'. It is often a matter 
of perpetual contestation. People living on the streets are not only too often denied access to basic source of livelihood in terms of shelter, income or primary healthcare but in many cases also criminalised and dehumanised by the city's systems of surveillance and exclusion.

Making space during Covid-19 in the City of Tshwane (Pretoria), in the form of 23 shelters and new longer-term spaces of accommodation, was therefore also marked by subversions, disruptions and reconstructions.

Subversion: When suddenly 20 older homeless men, mostly black, are dropped off in a predominantly white neighbourhood - a gated community in which most residents probably regards as a crime threat - it subverts the dominant narrative. If then, this shelter becomes a model shelter, with no real incidents, and a huge level of ownership taken by the residents for each other and for the space in which they find themselves, it further subverts - almost trashes - the narrative that wanted to keep them out because of how they were regarded. It could also be that the church itself, in opening their doors for the 20 men, was busy subverting their own theology: learning how to practice an option for the poor, in very concrete terms.

Disruption: Making space caused disruption of paradigms and comfort zones. Opposite the Brooklyn Police Station infamously picking up homeless persons at the beginning of lockdown and dropping them off involuntarily at shelters that were already full, on the behest of suburban residents claiming that homeless persons might hold risk of infecting them - there are two churches: a Pentecostal and an Anglican church. They are friends of each other, together with other churches in that vicinity. First, the Full Gospel Church opened up space to house homeless students, and then, homeless women with their children. A few days later the Anglican Church down the street opened up 20 spaces for homeless men. Suddenly, there were two homeless shelters in a suburb of Pretoria opposite to the police station, disrupting the status quo, disrupting the narrative of the police and disrupting the narrative of churches who still waited for permission to do their mission. They simply did what they knew they had to do.

Reconstructions: Making space is also about reconstructions - reconstructed relationships that previously failed between NGOs in the city; reconstructed spaces that were abandoned to now allow older homeless persons to move in permanently; reconsidered visions and missions, because Covid-19 stopped us in our tracks and some churches asked, what have we been busy with all along?

At least four of the churches who opened up spaces are now considering long-term open spaces and even redevelopment of their properties to include homeless individuals. What is fascinating is how these churches' theological rhetoric might not be liberationist; but in reality, they have started to practice an option for the poor in rather radical ways. This was done whilst some of us, who are radically verbose and very verbal in our radicality, failed to engage in the orthopraxy that marked these sisters and brothers. Theirs became a deep solidarity with Jesus, in their homeless sisters and brothers, and an affirmation of our common and intertwined humanity. It is a reminder of Gutierrez's (1988:8) insistence that rigorous orthodoxy without expression in orthopraxy might be fruitless.

Making space is a critical practice, not only opening up a right to the city for those denied but also opening up new possibilities of being church, as well as a reconstituted relationship between church and city. Government can be engaged critically not only through rendering critique but also through offering concrete proposals, and through demonstrating the proposals as embodied in local faith communities.

Richard Schaull (1991:36), in bringing leading figures of the Reformation in conversation with Liberation Theology, showed how Luther already made it possible for Christians to engage authority in critical ways, whilst at the same time providing 'an impetus for movements of radical renewal' which 'helped create space for the emergence of new patterns of community and new models of church'.

Schaull (1991:36) maintains: 'Luther sets in motion forces that have profoundly affected the struggles of liberation on the part of oppressed people to this day'. On the one hand, the undercover liberation theologian would find him- or herself in spaces where public policy and plans are crafted, where public healthcare is deliberated on and where human settlements are planned, designed and implemented; always doing so from the perspective of the excluded poor. On the other hand, what Luther and liberation theology have paved the way for is for the institutional church, time and again, to revisit her own roots and to align herself again with Jesus's core solidarities.

In the last instance, I also want to speak of making space in the context of Practical Theology. Schweizer (2019:145-152), with reference to global migration and the ways in which it changes local landscapes, calls for Practical Theology to make space for 'the religious other', which is no longer distanced but in close proximity. For Schweitzer, 'broadening the discipline beyond the traditional paradigms' is now critical. The "limitations of the "pastoral paradigm" and also of the "clerical paradigm"' have to be overcome in multireligious societies.

In the same way, I would argue, Practical Theology has to shift its focus beyond the 'believer' or 'non-believer' to the 'non-person' of liberation theology. The non-person, who is remote - 'outside the gate' - and, only occasionally, a subject of our service, fails to be at the core of our theological solidarity, enquiry, collaboration and action. Making space to allow the interlocution of the street homeless community - as subjects and partners in doing theology - provides an opportunity for Practical Theological discourse and 
engagement to be liberated from institutional orthodoxies, and re-aligned to the Spirit's work in history. The homeless 'non-person' becomes not only a central category for our theological reflection but a full participant in doing theology and shaping theological discourse.

The undercover liberation theologian will traverse various publics as they seek every possible opportunity to advance the primacy of the poor. She and/or he will be found in policymaking spaces, on urban back streets, in Covid-19 shelters, in traditional liturgical spaces and in academic institutions - not neutrally present, but, endlessly and deliberating finding gaps, or opening up cracks, to make space at different tables for those who are left out; even a central or privileged space, whereby they proclaim the centrality of dignity and beauty of humanity, of the left-out poor.

It is about making space. It is also about making plans.

\section{Making plans}

Making plans is not only something spontaneous or organic. The spontaneity required from a crisis such as Covid-19, and organic responses springing up all-over the city, then needs to be matched with deliberate and sensitive intent, and strategic deliberation. If we are indeed serious about not only sheltering homeless persons during crisis but about creating the conditions that would allow every single inhabitant of the city to access sources of livelihood and secure long-term shelter, in which they have options to choose from, there needs to be a plan. At the beginning of the lockdown in Tshwane, a joint plan was crafted to move an issue that was mostly marginalised by the city's dominant imaginaries, to the centre, with strategic and deliberate intent.

Liberation theologies are not merely intellectual deconstructions of systems that reduce the majority of the world's people to mere subjects, nor are liberation theological constructs meant merely to evoke utopian imaginaries. Doing liberation theology is to actively practice solidarity, analyse systemic failures, foster alternative imaginations, and, through all of that, conscientise and mobilise movements that will 'take a clear option against poverty, oppression, suffering and dehumanization' (Buffel 2015), as partners with 'the God of the Exodus and of Jesus the Christ (the liberator)'.

The undercover liberation theologian is drawn into the struggles of those who are poor or vulnerable, and, from inside their struggles, participate in movements in which the poor opts for their own liberation; or, in public spheres where decisions are often made about the poor without the poor themselves being present, seeking to translate an option for the poor concretely into various societal spheres. Making plans is a thrust towards moving the margins to the centre.

When Jannie Hugo or Jan Heese or Sanele Ngcobo do their public health work as a medical professor and medical doctor and health administrator, on the streets and in the shelters, they opt for the poor in the purest sense of the word. They take medicine to the streets, spending hours every day screening every individual, administering methadone as alternative to substance use, and rushing from shelter to shelter to practice God's caring justice.

The Covid-19 temporary shelters in Tshwane were decent spaces where people got three meals a day, cynically referred to by some suburban people, for the 'luxury' homeless people were rendered. But, of course, as image-bearers of God, homeless persons deserve to be embraced completely, as anyone else. It became an expression of an assertion found in 1 Corinthians 12:23, stating: '.. the parts that we think are less honourable we treat with special honour. And the parts that are unpresentable we treat with special modesty'.

Holistic care was provided and the right to shelter - which is a justice issue - at once also mediated healing in a fuller sense of the word. When I asked one of the men, at a shelter in Lyttleton, when did he last experience living at home, he told me only once for a year in 2016, in his whole life. But, he said, in this shelter he found meaning; he found love; he found that he needed to be on anti-depressants; he found a psychiatrist for the first time in his life; he found courage to start afresh.

Right now a post-lockdown plan is being crafted, to ensure that the 1800 people being sheltered temporarily will not be sent back to the streets but that new and lasting infrastructure will be created for homeless persons in Tshwane. Vacant city buildings are being identified and secured and the city's budgeting process should be aligned to the number of homeless people, to be housed adequately and as stepping-stone into making their own plans for a different future. An option for the poor needs to find expression in the investment made by the city in its most vulnerable citizens.

Making plans also include asking new questions about our own home institutions and their responses or apathies in the face of this crisis. Just one or two student residences on university campuses would have housed a large percentage of the homeless population during lockdown. My one colleague was reprimanded for raising this with the university executive, as if institutional preservation could ever be more important than the sacredness of life.

Having been exposed to the fault lines of society, in a much more visible way than ever, and having been exposed to our own complicity in ongoing inequalities, and our distance from the city's harshest failures, we tooas churches, faith communities, non-profit organisations, schools of theology and academic institutions at large need to consider making plans that will prioritise 'the least of these': not in patronising ways of temporary relief, but through rigorous analysis and a commitment to a radically restructured society in which the reality of one homeless person would be an offense that we are collectively guilty of. 


\section{Making known}

In making known, I consider Freire's (1972) pedagogy as conscientisation: to become acutely aware of reigning death-dealing forces on the streets, and our apathy and complicity in the face of these forces; but, also, to become conscious of our own agency, collectively, to bring about radical change. I speak of 'our' in a broad collective sense, proposing such consciousness-raising pedagogies to be fostered in various spheres, both amongst those who experience homelessness first-hand; those seeking to support homeless communities; officials and politicians tasked with public policy-making; as well as the general public that is often 'othering' homeless persons in ways that condemn them to perpetual inhumanity.

The undercover liberation theologian works endlessly to create spaces in which people can know, and be known, in the sense in which Parker Palmer (1993) uses it. ${ }^{5}$

How do we practice pedagogies of freedom in public spaces, where one sits with a hundred public officials often trapped in huge hierarchy and protocol? What does a pedagogy of freedom look like in those spaces? What does it look like amongst 20 men in a shelter who are not scared so much of being infected with the virus, but their fear is that lockdown will end, because it might mean going back to the street? What does it mean for the suburban church that risked losing their lives, their theologies and their reputations, in order to find it anew? What does a pedagogy of freedom look like amongst them?

We need to be deliberate in developing local pedagogies of 'the oppressed' (Freire 1972) and 'the oppressor' (Bacon 2015) (to use reductionist language), but also making known through making new and innovative spaces in which both resourcepoor ('oppressed') and resource-rich ('oppressor') as well as policy makers and practitioners could grapple together, making sense, unravelling, seeing, knowing and being liberated.

Making known in this context would be to depart from an assertion of the 'epistemic privilege of the oppressed' (Stenberg 2006:273); 'to cure "historical amnesia" by giving voice to the subversive "memory of the poor"' (Stenberg 2006:237); as well to embrace a praxis-approach to doing theology, which refuses to separate action and reflection, as 'truth is not something found in sacred texts, but is something made, enacted' (Bacon 2015:227). Liberation theology, understood thus, 'is never completed' but 'provides tools for ongoing work' (Bacon 2015:227).

The realities and uncertainties of Covid-19 brought us to a new knowledge of the disconnects in our society, the failures of our city and the apathies of our best efforts. It also raises profound questions of faith. Some speak in this time of the silence of God. Where is God then in all of this? Why is God not making known what is to be done? Has God forsaken us?

And yet, I am asking: could this only be the silence of an institutionalised God, who does not know how to operate under lockdown, when our loud worship services are shut down, and our institutionalised forms of religion inhibited? Is it only the silence of a God who has unlearnt the art of subversion, asking permission to be God? Or, is it the silence of a God theologised through reflection void of embodied action? Because is the free God really silent or just not known, because this God does not neatly fit our religious constructs and might be too far away from our institutional expressions of church and intellectual constructs of truth? This God might indeed only be found outside the gate.

In every encounter with small groups of homeless women or men, in the past weeks, I encountered the loud voice of a free God, who wants to set the captives free - a loud voice rising from the ashes; a loud voice disrupting the silences of too many churches; a loud voice crying out against theological institutions that foster machinations of power, ticking boxes of pretention, whilst failing the poor! I hear the loud voice of God in the man who says to me: 'I was homeless since I was $5^{\prime}$.

\section{Making change}

Finally, of course, undercover liberation theologians are all about liberating and transformational change. It engages in the practices of making space, making plans and making known, as ways of deconstructing layers of meaning which were exclusivist and oppressive, whilst allowing for prophetic irruptions into contemporary (hi)stories. By speaking of being an 'undercover' liberation theologian, the hiddenness is not in the clear bias or option for the poor; to the contrary, the hiddenness is more in the use of theological or pastoral identity, instead of taking on the posture of a different discipline 'to transform the discipline's presuppositions' in the direction of a liberationist agenda (Petrella 2008:150).

The undercover liberation theologian employs various tools and practices to centralise what is marginal, to give voice to that which was silenced and to make radical change, where the status quo dealt with repeated death. The posture of this theologian is not only that of critiquing and deconstructing but also that of imagining, writing, planning, speaking, subverting and acting a new reality into being. This might not always come as the final revolution, or ultimate overthrow of a corrupt and soulless state, but it will represent a serious crack in the dominant narrative - now allowing those who were historically excluded, equal space at the table, equal access to sources of power and freedom and equal participation in creating a household of humanity, from below, such as the change to be envisaged by this theologian. 


\section{In losing ourselves, freedom will break through: Subverting education that is suspect}

Our theological education is suspect. When I see what medical students do in the trenches, and engineering students creating apps to make the work of shelters easier, and theological students locked away because they are told to do so, our theological education is suspect.

Petrella (2017:336-338) speaks of the need to provide our theological students with multilingual skills, to hold their own in urban planning, and economic projections, and public health conversations - not needing to hide behind religious jargon to advance a liberationist agenda, because they are boldly multilingual; and simply present. He (2017) considers:

How does one make this happen in theological education? Firstly, theologians in schools of theology must get themselves to ask: how do we express solidarity with the poorest in our city, at a time such as this? Yet, this question does not get asked if a prior theological conviction is not an option for the poor. Secondly, theological education that can be liberating needs to allow for risks to be taken, both by students and lecturers, for solidarity to be embodied, and for dominant knowledges to be deconstructed. This will mean locating students and lecturers at homeless shelters across the city, under normal circumstances, but particularly in times of disaster. Thirdly, it will mean rethinking the location of the classroom, the content of the curriculum, and the pedagogical approach to be followed. (p. 338)

In doing above, maybe something of Petrella's (2017) vision for theological education can materialise, when he envisions schools of theology as schools of transformation:

It trains neither pastors nor professors; it trains undercover theologians and prophets. It educates broad-based transformers who enter, as undercover theologians, to subvert society and change it from many different points. This is a different theological school, one that educates a new theologian that can break free from the limitations that have impeded the spread of the liberationist vision beyond theology. (p. 338)

I wonder if Petrella is not right: it will be in losing ourselves in the messiness of public processes, in the discomforts of multiple tensions, in the suspicious spaces of public encounter, where uttering God will not make change necessarily, that the freedom of the unfree will start to break through - in these spaces, if we remain stubbornly, suspiciously, shrewdly and gently present.

The undercover liberation theologian inside the council chambers, the popular liberation theologian amongst the social movements, the pastoral liberation theologian disrupting and comforting their churches and the professional liberation theologian, questioning the validity of our sterile theologies, whilst showing another way - all need to hold on to each other, and be held by those who urge us on - those still on the outside, looking in.

\section{Acknowledgements Competing interests}

The author declares that he has no financial or personal relationship which may have inappropriately influenced him in writing this article.

\section{Author's contributions}

This article is my personal work.

\section{Ethical consideration}

This article followed all ethical standards for a research without direct contact with human or animal subjects.

\section{Funding information}

The research received no specific grant from any funding agency in the public, commercial or not-for-profit sectors.

\section{Data availability statement}

Data sharing is not applicable.

\section{Disclaimer}

The views expressed in the submitted article are the author's own and not an official position of the University of Pretoria.

\section{References}

Allison, S. \& Harper, P., 2020, 'Stay at home, Cyril said. But what about the homeless?', Mail \& Guardian, 2 April 2020, viewed 10 April 2020, from https:// mg.co.za/article/2020-04-02-stay-at-home-cyril-said-but-what-about-thehomeless/.

Baccaro, L. \& Papadakis, K., 2008, The promise and perils of participatory policy-aking, International Labour Organisation, Geneva.

Bacon, C.K., 2015, 'A pedagogy for the oppressor: Re-envisioning Freire and critical pedagogy in contexts of privilege', in M. Kappen, M.S. Selvaraj \& S.T. Baskaran (eds.), Revisioning paradigms: Essays in Honour of David Selvaraj, pp. 226-237, (eds.), Revisioning
Visthar, Bangalore.

Boff, L. \& Boff, C., 1986, Wat is Theologie van de Bevrijding?, AltioraAverbode, Apeldoorn.

Buffel, O., 2015, 'Bringing the crucified down from the cross: Preferential option for the poor in the South African context of poverty', Missionalia 43(3), 349-364. https://doi.org/10.7832/43-3-123

City of Tshwane Metropolitan Municipality, 2019, Council meeting of 25 July 2019, City of Tshwane.

De Beer, S., 2020a, 'Homelessness and Covid-19: Political, institutional and theological capacities and priorities', Spotlight Africa, 15 April 2020, viewed 5 May 2020, from https://spotlight.africa/2020/04/15/homelessness-and-covid-19-politicalinstitutional-and-theological-capacities-and-priorities/.

De Beer, S., 2020b, 'Homelessness and Covid-19: The miracle of Tshwane', Spotlight Africa, 21 April 2020, viewed 5 May 2020, from https://spotlight. africa/2020/04/23/homelessness-and-covid-19-the-miracle-of-tshwane/.

De Beer, S., 2020c, 'Homelessness and Covid-19 in the City of Tshwane: Doing liberation theology undercover. A conversation with Ivan Petrella', Unpublished Paper Read at an online Seminar - 'Living with and after COVID-19 - An interdisciplinary public theological perspective', 13 May, 2020, hosted by the Graduate Programme in Theology of the Pontifical Catholic University of Paraná at Curitiba, and the Beyers Naudé Centre for Public Theology, University of Curitiba, and the Beyers
Stellenbosch, Stellenbosch.

De Beer, S. \& Vally, R. (eds.), 2015, Pathways out of homelessness research report 2015, University of Pretoria, Pretoria.

Freire, P., 1972, Pedagogy of the oppressed, Penguin, London.

Groody, D.G. \& Gutierrez, G.A., 2013, The preferential option for the poor beyond theology, University of Nortre Dame Press, Nortre Dame, IN.

Gutierrez, G., 1988, A theology of liberation, Orbis Books, Maryknoll, NY.

Habermas, J., 1992, Between facts and norms, MIT University Press, Cambridge, MA. 
Hugo, J., 2017, 'Homelessness in Tshwane: Health report from the Department of Family Medicine, University of Pretoria', in S. De Beer \& R. Vally (eds.), Pathways out of homelessness research report 2015, pp. 14-17, University of Pretoria, Pretoria.

Kriel, I., Tembe, M.J.M. \& Mashava, V.R., 2017 'Homelessness in Pretoria: Exploring the survival challenges of the homeless and their right to the city', Development Southern Africa 34(4), 428-438. https://doi.org/10.1080/0376835X.2017.1310024

Louw, D.J., 2008, 'Space and place in the healing of life: Towards a theology of affirmation in pastoral care and counselling', Verbum et Ecclesia 29(2), 426-445. https://doi.org/10.4102/ve.v29i2.23

Ntuli, C., 2019, 'City of Tshwane's broad new strategy to help homeless hailed', Pretoria News, 16 October 2019, viewed 30 April 2020, from https://www.iol.co.za/pretorianews/city-of-tshwanes-broad-new-strategy-to-help-homeless-hailed-35070046.

Palmer, P., 1993, To know as we are known: A spirituality of education, Harper Collins, San Francisco, CA.

Petrella, I., 2008, Beyond liberation theology: A polemic, SCM Press, London.

Petrella, I., 2017, 'Liberation theology undercover', Political Theology 18(4), 325-339. https://doi.org/10.1080/1462317X.2017.1311058
Ramaphosa, C., 2020, Statement by President on escalation of measures to combat the Covid-10 epidemic, Union Buildings, Tshwane, viewed 05 May 2020, from
http://www.thepresidency.gov.za/speeches/statement-president-cyrilhttp://WWw.thepresidency.gov.za/speeches/statement-president-
ramaphosa-escalation-measures-combat-covid-19-epidemic\% $\% 2$-union.

Renkin, W. \& De Beer, S., 2017, 'The Tshwane homeless summit as dramaturgy: A contextual, trans-disciplinary epistemology from below', Development Southern Africa 34(4), 482-496. https://doi.org/10.1080/0376835X.2017.1331834

Schaull, R., 1991, The reformation and liberation theology. Insights for the challenges of today, Westminster/JohnKnoxPress, Louisville, KY.

Schweizer, F., 2019, 'Making space for the religious other in practical theology', in A. Vähäkangas, S. Angel \& K.H. Johansen (eds.), Reforming practical theology: The politics of body and space, vol. 1, pp. 145-152, International Association of Practical Theology Conference Series,Tubingen (umlaut u). https://doi. org/10.25785/iapt.cs.v1i0.65

Stenberg, S.J., 2006, 'Liberation theology and liberatory pedagogies: Renewing the dialogue', College English 68(3), 271-290, viewed 8 May 2020, from http:// digitalcommons.unl.edu/englishfacpubs/192.

Vellem, V.S., 2015, 'Black theology of liberation and radical democracy: A dialogue', Scriptura 114(1), 1-13. https://doi.org/10.7833/114-0-1111 